\title{
ESTIMATION OF THE THERMAL CONTACT CONDUCTANCE FROM UNSTEADY TEMPERATURE MEASUREMENTS
}

\section{DOLOČANJE KONTAKTNE TOPLOTNE PREVODNOSTI IZ NERAVNOTEŽNEGA MERJENJA TEMPERATURE}

\author{
Jiří Kvapil, Michal Pohanka, Jaroslav Horský \\ Heat Transfer and Fluid Flow Laboratory, Faculty of Mechanical Engineering, Brno University of Technology, Technická 2, 61669 Brno, \\ Czech Republic \\ kvapil@fme.vutbr.cz
}

Prejem rokopisa - received: 2013-10-08; sprejem za objavo - accepted for publication: 2014-03-28

doi: $10.17222 /$ mit.2013.238

\begin{abstract}
Thermal contact conductance is an important parameter for describing the heat transfer between two bodies. When two solids are put in contact and heat transfer occurs, a temperature drop is observed at the interface between the solids. This is caused by an imperfect joint, which occurs because the real surfaces are not perfectly smooth and flat. This paper describes an experimental device for the evaluation of the thermal contact conductance, which was designed and fabricated in the Heat Transfer and Fluid Flow Laboratory. This device was built mainly for simulating metal-forming conditions, which include high pressures (up to $360 \mathrm{MPa}$ ) and high temperatures (up to $1200^{\circ} \mathrm{C}$ ) in the contact of two solids. The principle of this investigation is the unsteady measurement of the temperatures of two solids that are put in contact under different conditions. The surface temperature and thermal contact conductance can be calculated from the measured temperatures by an inverse heat-transfer task. The measured temperature history and the calculated values of the thermal contact conductance for pilot tests are presented in this paper.

Keywords: thermal contact conductance, inverse heat conduction problem, heat-transfer coefficient
\end{abstract}

Kontaktna toplotna prevodnost je pomemben parameter za opisovanje prehoda toplote med dvema telesoma. Ko sta dve trdni snovi v stiku, se pri prenosu toplote opazi znižanje temperature na stiku med dvema trdnima snovema. To nastane zaradi nepopolnega stika, ker realne površine niso popolnoma gladke in ravne. Ta članek opisuje eksperimentalno napravo za oceno kontaktnega prevajanja toplote, konstruirane v laboratoriju za prenos toplote in toka tekočin. Naprava je bila zgrajena predvsem za simulacijo razmer pri preoblikovanju materialov, ki vključujejo velik tlak (do $360 \mathrm{MPa}$ ) in visoke temperature (do $1200{ }^{\circ} \mathrm{C}$ ) na stiku med dvema trdnima materialoma. Princip teh raziskav je neravnotežno merjenje temperature dveh trdnih snovi, ki sta v kontaktu v različnih razmerah. Temperatura površine in kontaktna prevodnost toplote se lahko izračunata iz izmerjenih temperatur $\mathrm{z}$ upoštevanjem inverznega prenosa toplote. V tem članku sta predstavljeni zgodovina merjenja temperature in izračunane vrednosti kontaktne toplotne prevodnosti pri opravljenih preizkusih.

Ključne besede: toplotna prevodnost kontakta, problem inverznega prenosa toplote, koeficient toplotne prevodnosti

\section{INTRODUCTION}

Heat transfer over an interface has been the subject of research for decades, as it plays an important role in applications such as nuclear-reactor cooling, the aerodynamic heating of supersonic aircraft and missiles, satellite thermal control, the packaging of electronics, turbine and internal combustion engine design, etc.

When two solids with different temperatures come into contact, heat transfer occurs. A temperature drop is observed at the interface between the solids because of the surface imperfections. No truly smooth surface really exists. In reality, the contact is created at only a few discrete points. The contact point size and the density depend on the surface roughness, the physical properties of asperities and the contact pressure. The real contactarea fraction is only $0.01-0.1 \%$ without pressure. Pressure is one of the most important parameters that can affect the real contact area. Nevertheless, for metals the direct contact takes an area of around $1-2 \%$ for several tens of $\mathrm{MPa}$ in the contact. ${ }^{1}$ The heat transfer is decreased due to the (air) layer partially filling the voids between the surfaces, although heat flows or radiates through these voids. Many models and empirical and semi-empirical correlations to predict the thermal contact conductance have been published. ${ }^{2}$ However, these models have restrictions in terms of the maximum contact pressure (up to $7 \mathrm{MPa}$ ) and temperature and are not convenient for an estimation of the thermal contact conductance in conditions simulating metal forming and hot rolling.

\section{METHODS OF MEASUREMENT}

Usually, thermal contact conductance is measured using steady-state experiments (Figure 1). ${ }^{3}$ The two bodies are in contact and their ends are cooled and heated. The temperature distribution is measured using thermocouples inside the bodies. After a couple of hours, the constant heat flux $q$ is obtained and the temperature drop $\Delta T$ at the interface is estimated by extrapolation. From this, the thermal contact conductance $h_{\mathrm{c}}$ can be calculated:

$$
h_{\mathrm{c}}=\frac{q}{\Delta T}
$$




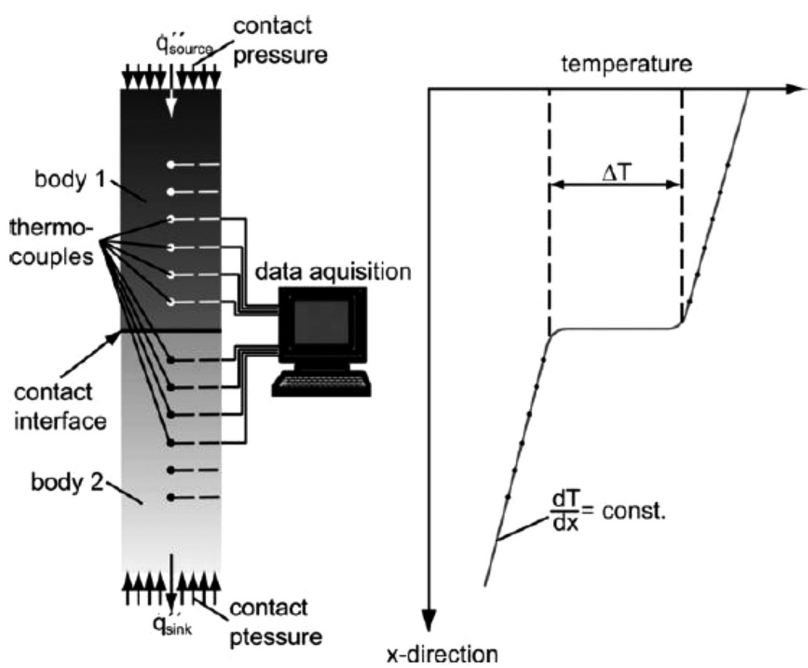

Figure 1: Experimental device for steady-state measurement of the thermal contact conductance ${ }^{3}$

Slika 1: Eksperimentalna naprava za ravnotežne meritve kontaktne toplotne prevodnosti ${ }^{3}$

The next procedure to estimate the thermal contact conductance is an unsteady measurement. This procedure is described here. Two thermocouples are embedded close to the surface of the bodies in contact. The measured temperature history is used for an inverse calculation and the thermal contact conductance is derived. This method is much faster but more difficult to calculate in comparison with steady-state experiments.

\section{EXPERIMENTAL PROCESS}

An experimental device (Figure 2) for estimating the thermal contact conductance in various conditions was

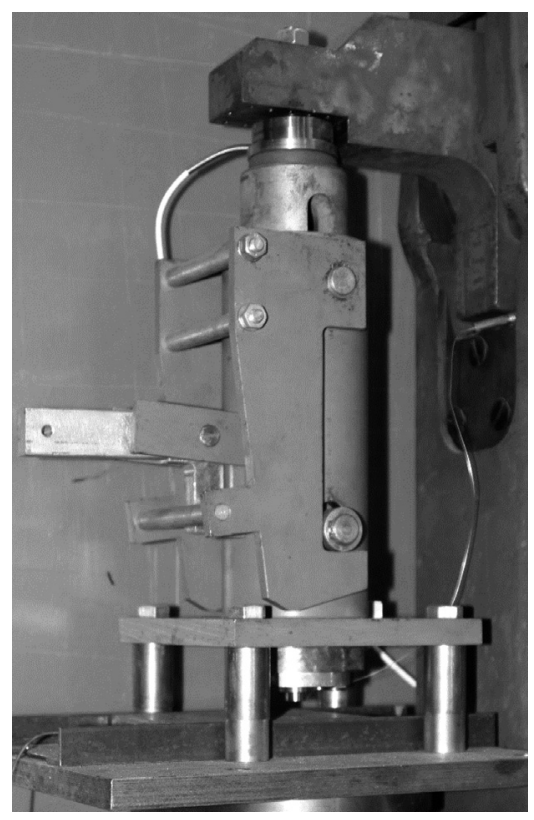

Figure 2: Experimental device

Slika 2: Naprava za preizkuse

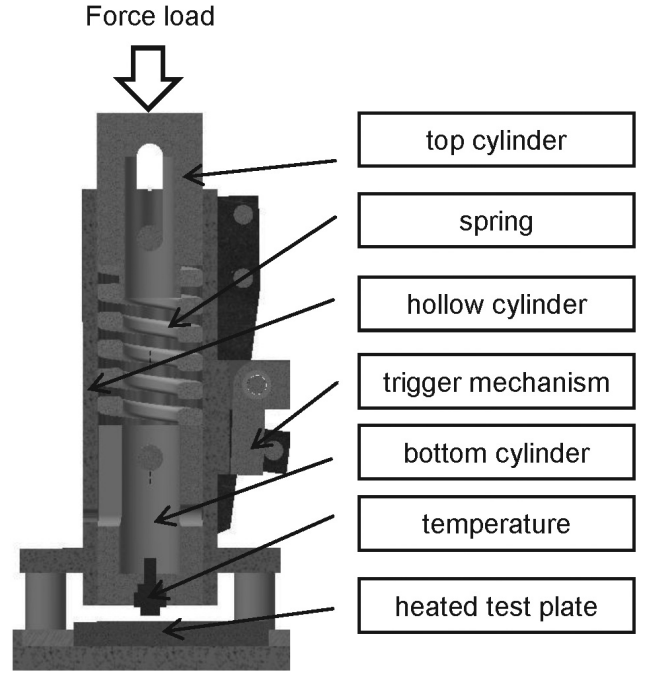

Figure 3: Cross-section of the experimental device Slika 3: Prerez naprave za preizkuse

built in the Heat Transfer and Fluid Flow Laboratory. The main part of the device is a steel body in the shape of a hollow cylinder. Two smaller cylinders, top and bottom, and a spring are located inside the hollow cylinder (Figure 3). A temperature sensor is embedded in the bottom cylinder and has a diameter of $12 \mathrm{~mm}$. The top cylinder is used for compressing the spring to the required force, which is measured by a force sensor. The trigger mechanism is used to prevent the bottom cylinder and the sensor from moving. The first thermocouple (type $\mathrm{K}$, diameter of $0.5 \mathrm{~mm}$ ) is built in the temperature sensor at a depth of $0.9 \mathrm{~mm}$ from the surface and the second thermocouple (type $\mathrm{K}$, diameter of $1.5 \mathrm{~mm}$ ) is in the test plate at a depth of $2 \mathrm{~mm}$ from the surface.

This device can be used for measuring a variety of initial conditions, like contact pressure (up to $360 \mathrm{MPa}$ ), temperature (up to $1200{ }^{\circ} \mathrm{C}$ ), different types of materials in contact, surface roughness and scales on the surface.

\subsection{Experimental procedure}

The experiment begins by heating the test plate to the required temperature. Independent of the heating, the

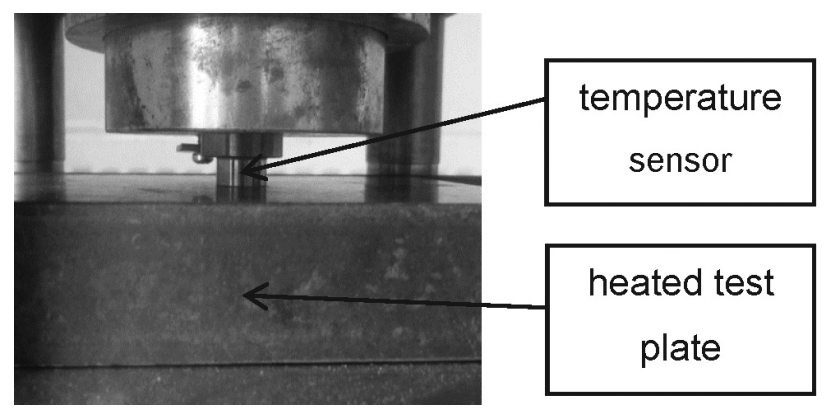

Figure 4: Contact of the temperature sensor and the heated test plate in detail

Slika 4: Detajl stika senzorja temperature in ogrevane preizkusne plošče 
spring is pressed to the required load. Then the test plate is inserted into the experimental device and the trigger mechanism is released. When the surfaces of the sensor and the test plate are in contact (see the detail in Figure 4), heat transfer occurs because of the different temperatures of the bodies in contact. The temperatures are measured and stored in the data logger.

Three experiments (Table 1) with different initial parameters were performed and the measured temperature history from Exp2 is shown in Figure 5. The time $0 \mathrm{~s}$ marks the time of contact.

Table 1: List of experiments

Tabela 1: Seznam preizkusov

\begin{tabular}{|c|c|c|c|}
\hline \multirow{2}{*}{ Test name } & \multirow{2}{*}{$\begin{array}{c}\text { Contact } \\
\text { pressure }\end{array}$} & $\begin{array}{c}|c| \\
\text { Initial } \\
\text { temperature }\end{array}$ & $\begin{array}{c}\text { Test plate } \\
\text { (roughness })\end{array}$ \\
\cline { 3 - 4 } & $25 \mathrm{MPa}$ & $330^{\circ} \mathrm{C}$ & grinded $\left(R_{\mathrm{a}} 0.8\right)$ \\
\hline Exp1 & $25 \mathrm{MPa}$ & $530^{\circ} \mathrm{C}$ & grinded $\left(R_{\mathrm{a}} 0.8\right)$ \\
\hline Exp2 & $25{ }^{\circ} \mathrm{C}$ & grinded $\left(R_{\mathrm{a}} 0.8\right)$ \\
\hline Exp3 & $70 \mathrm{MPa}$ & $820^{\circ} \mathrm{C}$ & \multicolumn{2}{|c}{} \\
\hline
\end{tabular}

The heat flux and the surface temperatures of the temperature sensor and the test plate during the experiment are calculated by the inverse heat-conduction task.

\section{INVERSE HEAT-CONDUCTION TASK}

Two 2D models, one for the temperature sensor and the second for the test plate, were used for the numerical computation. The models also include the thermocouples inside because the homogeneity of the material is disrupted by the inserted thermocouples, and thus the temperature profile is also disrupted. A one-dimensional sequential Beck's approach ${ }^{4-6}$ is used to compute the heat fluxes and the surface temperatures of the temperature sensor. The main feature of this method is the sequential estimation of the time-varying heat fluxes and surface temperatures and using future time-step data to stabilize the ill-posed problem. The measured temperature history from the temperature sensor is used as the input $T^{*}$ in the minimizing equation:

$$
S S E=\sum_{i=m+1}^{m+f}\left(T_{i}^{*}-T_{i}\right)^{2}
$$

where $m$ is the current time, $f$ is the number of future time steps and $T_{i}$ is the computed temperatures from the forward solver ${ }^{7}$. The SSE denotes the sum of square errors. The value of the surface heat flux $q$ at time $m$ is:

$$
\begin{gathered}
q^{m}=q^{m-1}+\frac{\sum_{i=m+1}^{m+f}\left(T_{i}^{*}-\left.T_{i}\right|_{q^{m}=0}\right) \cdot \zeta_{i}}{\sum_{i=m+1}^{m+f}\left(\zeta_{i}\right)^{2}} \\
\xi_{i}=\frac{\partial T_{i}}{\partial q_{m}}
\end{gathered}
$$

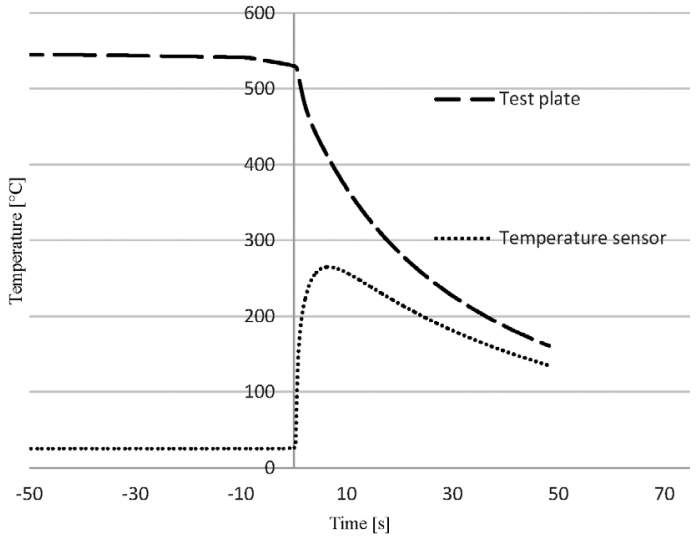

Figure 5: Temperature history of Exp2

Slika 5: Potek temperature pri Exp2

where $\zeta_{i}$ is a sensitivity coefficient at time index $i$ to the heat-flux pulse at time $m$. The temperatures $\left.T_{i}\right|_{q^{m}=0}$ at the thermocouple location of the temperature sensor computed from the forward solver use all the previously computed heat fluxes without the current one $q^{\mathrm{m}}$. When the heat flux is found for time $m$, the corresponding surface temperatures of the temperature sensor $T_{\text {surf } 1}^{m}$ and the test plate $T_{\text {surf } 2}^{m}$ are computed from the forward solver using $q^{\mathrm{m}}$ as the boundary condition in the contact area for the temperature sensor and the test plate. Using this procedure, the whole heat-flux history and the surface-temperature history are computed. When the surface heat flux $q^{\mathrm{m}}$ and the surface temperatures $T_{\text {surf } 1}^{m}$ and $T_{\text {surf } 2}^{m}$ are known, the thermal contact conductance $h_{\mathrm{c}}$ is computed from:

$$
h_{c}^{m}=\frac{q^{m}}{\frac{\left(T_{\text {surf } 2}^{m}+T_{\text {surf } 2}^{m-1}\right)}{2}-\frac{\left(T_{\text {surf } 1}^{m}+T_{\text {surf } 1}^{m-1}\right)}{2}}
$$

\section{RESULTS}

The computed heat-flux history and surface-temperature histories of the bodies in contact from Exp2 are shown in Figures 6 and 7.

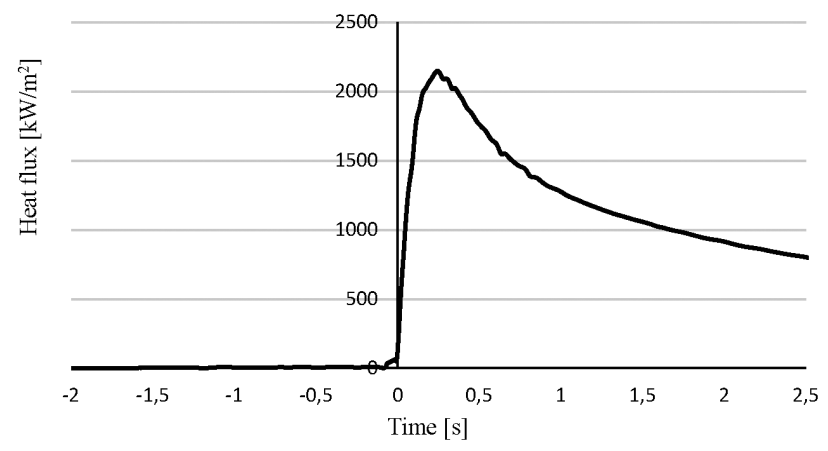

Figure 6: Computed heat-flux distribution of Exp2 Slika 6: Izračunana razporeditev toka toplote po Exp2 


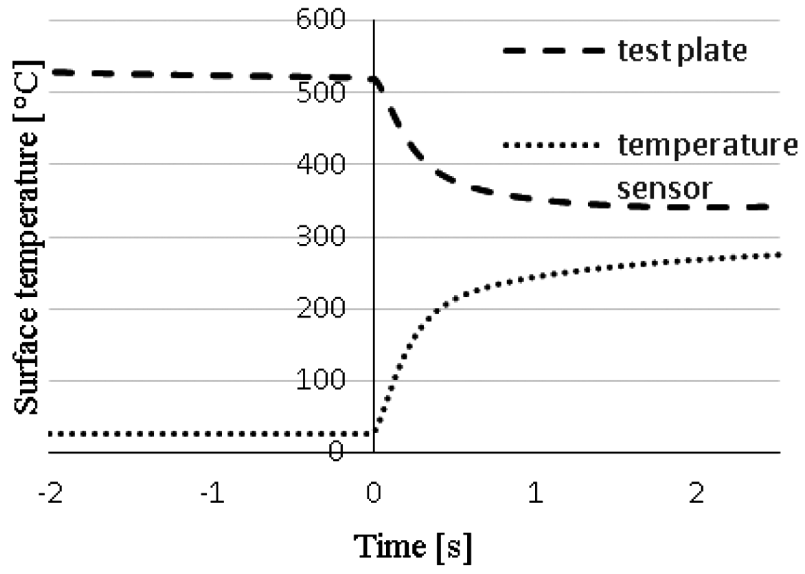

Figure 7: Computed surface temperatures of Exp2 Slika 7: Izračunane temperature površine pri Exp2

The inverse calculations, made for all the experiments and results in the form of thermal contact conductance, are shown in Figure 8.

Fieberg $^{3}$ dealt with the unsteady measurement of thermal contact conductance using a method where the temperature is measured using a high-speed infrared camera. During the experiments, he focused on conditions similar to those in a combustion engine, where the contact pressure can be up to $250 \mathrm{MPa}$ and the temperature can be up to $630{ }^{\circ} \mathrm{C}$. He mainly tested steel-aluminium alloys, but he also published an experiment with steel. His distribution of the thermal contact conductance with steel bodies for $34 \mathrm{MPa}$ in the contact and a starting temperature at $270{ }^{\circ} \mathrm{C}$ is shown in Figure 8 .

Theoretically, the distribution of the thermal contact conductance with time should be constant. This corresponds quite well with our experiments, and also with Fieberg $^{3}$, but in our case, directly after the contact, it takes some time (around $0.3-0.5 \mathrm{~s}$ ) to stabilize the level of thermal contact conductance. This is caused by vibrations after the sudden contact of the temperature sensor and the heated test plate. It is obvious that an important influence on the thermal contact conductance comes from the contact pressure and the initial temperature of the test plate.

\section{CONCLUSION}

In this paper, an experimental device for the unsteady measurement of the temperatures of two solids that are put in contact has been described. New numerical models for computing the thermal contact conductance from the temperature history were developed, three pilot experiments were made and the results were presented. The computed distributions of the thermal contact conductance show a strong dependence on the contact pressure and the initial temperature. The estimated thermal contact conductance for a contact pressure of $25 \mathrm{MPa}$ and an initial temperature of $330{ }^{\circ} \mathrm{C}$ is $9100 \mathrm{~W} /\left(\mathrm{m}^{2} \mathrm{~K}\right)$, while for $25 \mathrm{MPa}$ and $530{ }^{\circ} \mathrm{C}$ it is $12200 \mathrm{~W} /\left(\mathrm{m}^{2} \mathrm{~K}\right)$ and for 70 $\mathrm{MPa}$ and $820{ }^{\circ} \mathrm{C}$ it is $35500 \mathrm{~W} /\left(\mathrm{m}^{2} \mathrm{~K}\right)$. These results

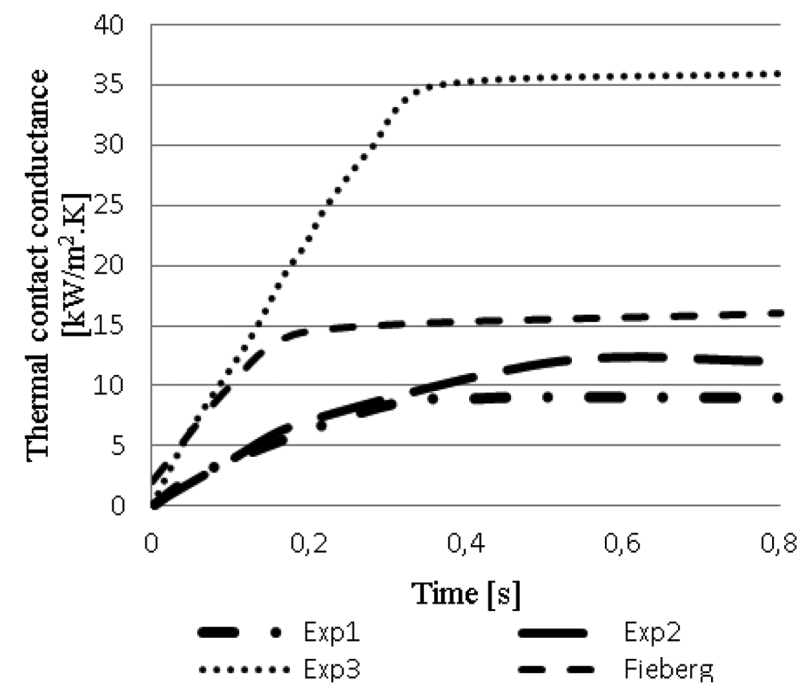

Figure 8: Distributions of thermal heat conduction for various initial conditions

Slika 8: Razporeditev toplotne prevodnosti za različne začetne razmere

could be used in numerical simulations of metal forming and hot rolling where the values of thermal contact conductance in the interface between two solids are still missing. Additionally, there is a need for similar experiments focusing on the influence of the thermal contact conductance by surface roughness, type of material and thickness of the scales.

\section{Acknowledgement}

The research in the presented paper has been supported within the project No. CZ.1.07/2.3.00/ 20.0188, HEATEAM - Multidisciplinary Team for Research and Development of Heat Proceeding.

\section{REFERENCES}

${ }^{1}$ F. P. Bowden, D. Tabor, The friction and lubrication of solids, Oxford University Press, London 1950, 391 p.

${ }^{2}$ A. Wang, J. Zhao, Review of prediction for thermal contact resistance, Science China Technological Sciences, 53 (2010) 7, 1798-1808, doi:10.1007/s11431-009-3190-6

${ }^{3}$ C. Fieberg, R. Kneer, Determination of thermal contact resistance from transient temperature measurements, International Journal of Heat and Mass Transfer, 51 (2008) 5-6, 1017-1023, doi:10.1016/ j.ijheatmasstransfer.2007.05.004

${ }^{4}$ J. Beck, B. Blackwell, C. R. Clair, Inverse heat conduction: ill-posed problems, Wiley, New York 1985, 308 p.

${ }^{5}$ M. Pohanka, K. A. Woodbury, A Downhill Simplex method for computation of interfacial heat transfer coefficients in alloy casting, Inverse Problems in Engineering, 11 (2003), 409-424, doi:10.1080/ 1068276031000109899

${ }^{6}$ M. Raudensky, Heat Transfer Coefficient Estimation by Inverse Conduction Algorithm, International Journal of Numerical Methods for Heat and Fluid Flow, 3 (1993) 3, 257-266, doi:10.1108/ eb017530

${ }^{7}$ W. J. Minkowycz, E. M. Sparrow, J. Y. Murthy, Handbook of Numerical Heat Transfer, 2nd edition, John Willey \& Sons, New Jersey 2006, 968 p. 